\title{
Toward a Roman Dialect of Empire
}

\section{Anatomies of Roman Imperial Government}

This, then, is the lay of the different parts of our inhabited world; but since the Romans occupy the best and the best-known portions of it, having surpassed all former rulers of whom we have record, it is worthwhile, even though briefly, to add the following account of them ... Of this whole country that is subject to the Romans, some is indeed ruled by kings, but the Romans retain the other part, calling it "provincial" (eparchian), and send governors (hégemonas) and collectors of tribute (phorologous). But there are also some free cities, some of which came over to the Romans at the outset as friends, whereas others were set free by them as a mark of honour. There are also some potentates and phylarchs and priests subject to them. Now these live in accordance with certain ancestral laws. But the provinces have been divided in different ways at different times, though at the present time they are as Augustus Caesar (Kaisar ho Sebastos) arranged them; for when his native land committed to him the foremost place of authority and he became established as lord for life of war and peace, he divided the whole land into two parts, and assigned one portion to himself and one to the people.

Strabo, Geography 17, 3, 24-5, Loeb tr. H. L. Jones with minor adaptations

There are many ways of starting a conversation about empire and political cultures in the Roman world. Modern accounts of the Roman

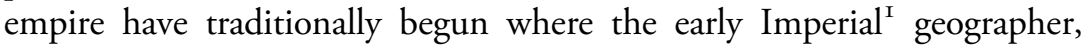
Strabo, writing between the 3 OS BCE and the 2OS CE with a perspective that zooms impressively between the global and the highly particular, ends his panoramic account of a Roman world newly centered on monarchy.

\footnotetext{
I Modern usage makes the fact that the Romans possessed an empire before they had emperors seem counter-intuitive. As a compromise, I capitalize Empire and Imperial when referring specifically to the period from January 27 BCE, when Augustus was granted this honorific name by the Roman senate. When referring either to the empire of the Republican period and its condition ("imperial"), or to empire spanning the Republican period and the world of emperors, I do not capitalize these terms.
} 
Something along the lines of Strabo's anatomy of the Roman empire's parts, its personnel and basic institutions (provinces and governors, taxcollectors, the princeps himself, free cities, kings and other rulers paradoxically both subject to Rome and using their own ancestral laws), is generally reproduced as a straight description of Roman administration, how the Roman empire really was. ${ }^{2}$

Modern anatomies of Roman administration that lay out its constituent parts and the relationships between them are rooted in masterful nineteenth- and earlier twentieth-century analyses, a tradition dominated by Mommsen's account in his Römisches Staatsrecht (I87I-I888) of the Roman state as a well-oiled machine that operated according to recoverable, legal rules. But there is, of course, no such thing as an unengaged and merely descriptive anatomy of the Roman empire. The telling of parts and powers is inevitably selective, aspirational, idealizing, or corrective, in various measures, whether it forms part of an official, Roman-state sponsored context, such as the later Republican repetundae ("extortion") law (Crawford I996, I, I), or a literary text such as Strabo's Geography.

Strabo's panoramic vision of the distinctly Roman political geography of most of the inhabited world translates Roman imperial power into a centuries-old Greek vocabulary of sovereignty and rule with its own, substantial baggage and different semantic ranges. Along with this vocabulary go centuries-old expectations: highlighting free cities signals the ancient motif of "surrender-and-grant" that makes self-government the gift of imperial rulers, a prime illustration of the distinctive currencies of premodern empires, balancing precariously but productively on local structures and their bargaining power. As Strabo's Geography reaches its grand finale in this passage, Augustus' division of the provinces marks recognition of the princeps' supremacy over the best part of the inhabited world: Strabo's very project of universal geography is underpinned by the hereditary monarchy established by Augustus (cf. 6, 4, 2). There was no inevitable connection between ideas of universal history and monarchy: Strabo had to work hard to make this association seem natural and inevitable, just as the first princeps worked hard to place himself at the center of a vast, reordered world in his Res Gestae. At the same time, Strabo's connection of his project with that of Augustus alerts us to broader issues of agency and implication in the imperial project within

${ }^{2}$ Excellent introductions to Roman imperial administration include Millar I981a; Braund 1988; Lintott 1993; Bowman 1996; Eck 2000; Galsterer 2000; "how the Roman empire really was": cf. Finley I986a. 
his Geography. The history of Strabo's own family, from Amaseia on the Black Sea, historically closely allied to the local kings, and with Mediterranean networks of its own, is enmeshed within, and gains and loses from, the dynamics of rival powers and individuals in the eastern Mediterranean and Asia Minor. ${ }^{3}$

Rather than presenting a "bird's-eye" view of the structures and operation of the Roman empire, this chapter focuses on the dynamic, ongoing processes of conceptualizing, enacting, and claiming modes of power and sovereignty associated with the Roman imperial state. I begin with a discussion of the Roman imperial state's self-fashioning at the interface with older and competing systems and expectations of rule, and move on to consider the ways in which various groups and individuals were able to use and claim the Roman state's modes of power and sovereignty for various ends including self-actualization.

\section{Among Empires}

What we might think of as some of the classic, distinctive concepts and institutions of the Roman empire - including imperium in the sense of a single, territorial entity ("the Roman empire"), ${ }^{4}$ provinces as administrative units of this territorial entity, Roman governors, the articulation of cities outside Rome as Roman or Latin in legal terms, the creation of community-level hotspots (theaters that juxtapose local elites with the Caesars, reproductions of the Forum Augustum, sanctuaries of the "imperial cult") that localize the power and centrality of Rome, instantly recognizable symbols of sovereignty and officialdom that invited appropriation (the emperor's head on the obverse of coins, consular dating, Latin or Latininfluenced legalese), and the Roman citizenship exercised as a privilege and honor within one's local town - are all products of processes that took many years to formulate in these particular ways. The early history of Rome's Republican empire is one of negotiation between ideas and institutions of imperial power specific to Rome and preexisting or competing

3 Greek translations of Roman imperial power and institutions: Mason 1974; Crawford I977; Richardson 1979; Derow I979; Dubuisson I985; "surrender-and-grant": Ma 2002, I I I-I3, with bibliography; Strabo and his contexts: Bowersock 1965; Prontera 1984; Clarke 1997; 1999a; Dueck 2000; Dueck, Lindsay and Pothecary 2005; universal history: Clarke I999b; Alonso-Núñez 2002; Liddel and Fear 20I0; Augustus' own geographical projects: e.g., Nicolet I991; Cooley 2009.

4 "Among empires" alludes to Maier 2006, but my interest is in the ways in which ancient understanding and actions were affected by experience of different imperial systems (cf. Dandelet 2014 for an early modern case-study) rather than in how we might compare historical empires from our early twenty-first-century perspective. 
ideas and institutions of empire in the Mediterranean world, often involving the literal or figurative processes of translation. While long memories of empire are most readily apparent in the eastern Mediterranean, mediated to us primarily in the Greek language and via Greek cultural motifs, comparable processes also played out in the western Mediterranean as well as in northern Europe.

Polybius' later second-century BCE account of "by what means and under what kind of government the Romans in fewer than fifty-three years succeeded in subjecting almost the whole inhabited world to their sole rule $(\operatorname{arche}) "(\mathrm{I}, \mathrm{I}, 5)$ beautifully illustrates these processes. It begins with the Romans crossing the sea to Sicily in $264 \mathrm{BCE}$ and ends in $\mathrm{I} 46 \mathrm{BCE}$ with the sacks of Carthage and Corinth. In writing of Rome's rise, Polybius engaged in an early kind of "comparative empires" exercise. This is explicit in his "succession of empires" scheme that starts with the Persians and continues with Sparta and Macedonia, culminating in Rome as the most recent and greatest $(\mathrm{I}, 2)$. It is implicit throughout his narrative in the continuum of imperial vocabulary and institutions he applies to Rome and to other competing, expansionist states in the Mediterranean, both Greek and "barbarian," including Carthaginians, Syracusans, and the Oscan-speaking Mamertini (former mercenaries of Agathocles, ruler of Syracuse). The "succession of empires" motif first appears in historical writing of the classical period, but it is a key feature of Hellenistic and Roman historical geography. It is more than just a literary trope: it indicates the process of modeling and abstracting a concept of empire, and it suggests both the typical morphology and behavior of empires and past precedents for dealing with them. ${ }^{5}$

These processes are apparent at least as early as the fifth century $\mathrm{BCE}$ both in the more reflective contexts of historical writing and within the ideology of the Athenian empire. Athens engaged extensively with ideologies and practices of the Achaemenid (Persian) empire, which arguably provided the quintessential model of what empire was. The most significant feature is the regularization of tribute, but we should add to this garrisons, colonies, and dedicated, supervisory personnel, all of which would come to add up to a recognizable and long-lasting "package" of empire in the Mediterranean world. Persian models informed the language of imperial ceremonial and imperial centers. The procession depicted on

\footnotetext{
5 Modern "comparative empire" approaches that include the Roman empire include Doyle I986; Alcock et al. 200I; Burbank and Cooper 20I0; Mutschler and Mittag 2008; Scheidel 2009; Vasunia 20 I I for "succession of empires," e.g., Momigliano 1982, 542-9.
} 
the Parthenon frieze recalls that of the reliefs of the Apadana, the audience hall of the palace of Persepolis, even if the public ideologies are dramatically different. ${ }^{6}$

The preexistence of models of empire and behaviors associated with it especially encourage both the self-conscious following of patterns and the explicit rejection of major elements, often simultaneously. Athens' selfconscious reception of Persia as an imperial model anticipates the importance of the Achaemenid and Pharaonic past, as well as that of other Near Eastern kingdoms, for the successor kingdoms of Alexander the Great. These processes of self-fashioning with reference to predecessors are nicely illustrated in later foundation stories of Macedonian rule that involve the deeds of Alexander the Great, involving the "wedding" of Macedonian and Achaemenid practices in dress and ceremonial as well as the literal marriage of Alexander's Companions and ordinary soldiers to Asian women (Plut. Alex. 45, I-2; 47, 3-5; 70, 2; De Alex. fort. I, 7-8; 2, 6; Arr. Anab. 4, 7, 4; 4, 9, 9-II, 9; 7, 4, 4-8; 6, I-5). ${ }^{7}$

Herodotus' later fifth-century в ве account of the rise of the Persian empire and its defeat by the Greeks, written with Athens on the cusp of imperial ascendancy, and Thucydides' early fourth-century account of the rise and fall of the Athenian empire, written with consciousness of its defeat by Sparta in $404 \mathrm{BCE}$, work through more reflectively the behavior and trajectories of empire. Both accounts are prime examples of a classical trope and strategy of representing empire as a type of tyranny, the antithesis of the idealized self-direction of the polis and its citizens. As Herodotus traces the origins of Greek-barbarian conflict, he looks to the beginnings of Greek subjugation to barbarian power: while it was painfully clear to some fifth-century observers that you did not have to be a barbarian to be a tyrant, there was nevertheless something barbarous about tyranny. Herodotus' telling of events on which he presumes to pronounce truth or falsity begins with the arche of Croesus of Lydia over the Greeks of western Asia Minor in the mid-sixth century, an ongoing subjugation exacted by tribute that runs in parallel with a relationship of "friendship" extended to the Spartans. Croesus' archē is explicitly distinguished from smash and grab raids and is the antithesis of freedom (I, 5, 3-I, 6). Tribute and "enslavement" likewise signal the beginnings of Athenian arche in Thucydides' account of the period between the Persian and the

6 Root I985; Boedeker and Raaflaub I998; Raaflaub 2009.

7 Kuhrt and Sherwin-White I991; Sherwin-White and Kuhrt I993, 40-52; Hatzopoulos I996; Ma 2002; 2003, I83-6; 2009; Briant 2010; Manning 2010. 
Peloponnesian Wars ( $1,89-\mathrm{II} 8$ ), accelerating to the point at which Athens could be portrayed by her own leaders as a "tyrant city" (2, 63, $2 ; 3,37,2)$, despite her professed aim of leading an alliance to continue hostilities against the Persian king. ${ }^{8}$

Croesus' option of subjugation through "friendship" and Athens' professed aim alert us to the degree to which ancient imperial relationships relied on "soft" mechanisms that were regularly articulated as being mutually beneficial. ${ }^{9}$ Imperial relationships were brokered in part through traditional, ostensibly voluntary networks that maintained connection and ordered power and proximity in the Mediterranean world, including friendship, gift-exchange and "kinship diplomacy." Rome's expedition to Sicily in 264 BCE was made in response to the appeal of the Oscanspeaking Mamertini, former mercenaries of Agathocles of Syracuse who had gone rogue and taken over the Greek city of Messana. Finding themselves in trouble with Syracuse, they appealed to Carthage, who installed a garrison, and to Rome, appealing to ties of kinship, homophylia, perhaps based on a notion of common Italian-ness, a notion with its own peculiar history of power relationships (Polyb. I, 8-I2). This episode illustrates beautifully broad awareness across international communities in the third-century вСе Mediterranean of how to play the imperial game in its variations, with the stakes or counters that made most sense in any particular social and cultural environment. ${ }^{\text {IO }}$

Rome's experience of international languages and practices of empire did not begin only when it crossed the sea to Sicily in 264 B CE but was apparent already in modes of self-representation, victory, and continuous subjugation of multi-ethnic peoples (including Greeks and "Hellenized" communities) exercised in Italy decades earlier. Rome's management and domination of vast tracts of space by road-building, the annexation of territories, and the movement of whole populations, militaristic colonial foundations, and concessions of status such as limited grants of citizenshipwithout-the-vote suggest engagement with international models of domination, including those of the Deinomenids of Sicily and, most recently, the Hellenistic successor kingdoms to Alexander the Great. Coin-motifs of third-century Rome, eclectic in comparison with the coinages of other

${ }^{8}$ For empire as tyranny, see Tuplin 1985; cf. Lavan 2016.

9 Cf. the pioneering initiative of Badian I984 (Ist edn. 1958) to portray a Roman empire fueled by interpersonal relationships rather than by the impersonal structures of "annexation," even if the role of patronage is over-emphasized (cf. Eilers 2002).

ro Kinship diplomacy and friendship: cf. Sahlins 1972; Jones 1999; Morris 1986; Erskine 200I; Burton 20II, 63-75; Mamertini: Russo 2012. 
southern Italian cities, fasten for their inspiration particularly on the martial and imperial iconography of Athena, goddess of Athens, and Alexander. ${ }^{\text {II }}$

Livy, writing in Latin in the Augustan age, but almost certainly drawing on the near-contemporary Greek account of Polybius, depicts the Roman proconsul L. Aemilius Paullus delivering his pronouncement on the settlement of Macedonia in I67, after the Roman defeat of King Perseus, and the dissolution of the Macedonian kingdom as follows:

Aemilius gave notice for the councils of ten from all the cities to assemble at Amphipolis and to bring with them all archives and documents wherever they were deposited, and all the money due to the royal treasury. When the day arrived he advanced to the tribunal, where he took his seat with the ten commissioners, surrounded by a vast concourse of Macedonians. Though they were accustomed to royal power (regio imperio), this novel assertion of authority filled them with fear; the tribunal, the clearing of the approach to it through the mass of people, the herald, the aide, all these were strange to their eyes and ears and might even have appalled allies of Rome, to say nothing of a vanquished enemy. After the herald had called for silence Paullus, speaking in Latin, explained the arrangements decided upon by the senate and by himself in concert with the ten commissioners; Cn. Octavius the praetor, who was also present, translated the address into Greek. First of all it was laid down that the Macedonians were to be a free people, possessing their cities and fields as before, enjoying their own laws and customs and electing their annual magistrates. They were to pay to Rome half the tribute which they had been paying to the king. Secondly, Macedonia was to be broken up into four separate cantons. (Livy 45, 29, Loeb tr.)

This evocative representation of the spectacle of Roman imperial power zooms in on the issues of translation (literal and metaphorical) that are an intrinsic aspect of operating "among empires," acute at the initial point of succession but always there at the interface between the dominant power and older or alternative sources of power. Aemilius Paullus' judgment has much in common with other highly charged type-scenes of the arrival of Roman power: it is somewhere on a spectrum between Polybius' account of Scipio Africanus capturing New Carthage with highly calibrated terror (Io, I 5, 4-6), and the handshake that confirmed amicitia, familiar from both literary and artistic representations. ${ }^{\mathrm{I} 2}$

I Roman imperial practices in Italy: Frederiksen 1984, I93-8; Purcell I990b; I994; Dench 2003; coin-motifs: Burnett 1986.

${ }^{\text {I2 }}$ Terror: Chapter 4; friendship: Burton 20II, I-2. 
It was hard to decouple empire from monarchy in the ancient world, however loud protests might be from and on behalf of the Athenian democracy or the Roman Republic. Although the world into which the Romans expanded was not exclusively monarchical, it was one dominated by the model of monarchy, specifically the model of Alexander cultivated by and much beyond the Hellenistic successor kingdoms (the Antigonids, the Seleucids, and the Ptolemies). In the passage from Livy, the spectacle is on one level all about the new power's self-distancing from the Macedonian monarchy. Its emphasis on "freedom" and on halving the tribute plays on both immediate and historical knowledge of what empire was, while the alien trappings and ceremonial of Roman power and the use of a foreign language drive home the cultural difference. ${ }^{\mathrm{I} 3}$

The idea of Rome as the antithesis of kingship surfaces strongly in ancient traditions on the Seleucid king Antiochus IV Epiphanes. The king's madness (for which he earned the alternative epithet "Epimanes") is manifested in his topsy-turvy behavior, dressing up as a Roman Republican magistrate, canvassing for election, and sitting on an ivory chair to dispense justice. The idea of Romans as not-kings was not just an intellectual game. We can see this from the passage of $I$ Maccabees, a Jewish text written in Greek around IOо вCE, and treating the dramatic date of ${ }_{16} \mathrm{I}$ BCE, with Judas Maccabaeus seeking alliance with the Romans. Among the attractions of the Romans is that, despite the fact that they are both king-makers and destroyers of kingdoms, there is no king, no-one who wears the trappings of kingship, diadems and purple, even if there is, tantalizingly, only one man chosen to rule them each year (8, I I-I6). ${ }^{14}$

The "natural" opposition between regal Macedon and Republican Rome quickly breaks down in the passage from Livy, just as the real-life boundary could be usefully fuzzy: monarchy and the Roman Republic sometimes operate as polarities and sometimes as analogies. Having the Roman propraetor, Cn. Octavius, translate the proconsul's proclamation into Greek underlines the power of appropriation, just as bilingual and even trilingual inscriptions articulate ancient imperial powers' mastery of multiple systems and cultural groups. When the ceremonial associated with a Roman Republican proconsul is compared with "regal power," the use of the Latin word imperium here collapses the difference between

13 A more benign version of grappling with alien models at the "coming of Rome" is apparent in importation of the loan-word patrōn in inscriptions of Greek cities from the late second century BCE to express a new relationship that no Greek term quite encapsulated: Eilers 2002.

${ }^{14}$ Antiochus IV Epiphanes: Polybius 26, I, 5-7 = Athen. 5, I93d; Diodorus 29, 32; cf. Livy 4I, 20, who is significantly less interested in Antiochus' cultural and constitutional inversions. 
king and magistrate. Imperium signified the power vested in certain of the highest officers of the Roman state (praetors, propraetors, consuls, proconsuls, dictators, and masters of the horse), specifically the power to exact obedience to their orders, symbolized by the fasces that functioned as a portable punishment and execution kit. By the mid-second century BCE, imperium was beginning to acquire the more abstract meaning of the "sway" of the Roman people, their imperial rule. The terror inspired by the spectacle of Roman power even among those used to regal ceremonial might remind us of Polybius' tripartite, post-Aristotelian analysis of the Roman state, which identifies consuls as the "monarchical" element (and the senate and Roman people respectively as the "aristocratic" and "democratic" elements) (6, I I, I I-I 8). ${ }^{\text {I5 }}$

Roman imperatores were slotted into regal roles with some regularity, with more or less emphasis on the awkwardness of fit. One famous example involves L. Aemilius Paullus again, upcycling an inscribed pillar base at Delphi that was intended for a golden statue for Perseus, king of Macedon, literally slotting himself in to the place reserved for Perseus, and inscribing it in Latin thus: "L. Aimilius L. F. inperator de rege Perse Macedonibusque cepet" ("Lucius Aemilius, son of Lucius, imperator, took this from King Perseus and the Macedonians") (CIL I [2] $622=I L L R P$ 323). Aemilius' action acknowledges the symbolic place of Delphi as a center of the Greek world in the tradition of other aspiring superpowers who had made dedications there, including Croesus of Lydia. The phrasing of the inscription marks the parallel between Aemilius Paullus and Perseus but highlights the differences embodied also in the use of Latin: "inperator" vs. "rex." At the same time, Aemilius Paullus explicitly trumps Perseus: his inscription makes the gift to Apollo that the Macedonian king had intended into war booty as well. ${ }^{16}$

There are many other instances of Roman authorities slotting themselves into, or being slotted into, the spaces newly vacated by Hellenistic monarchy, including palaces and public buildings of the old regimes. Cicero's depiction of Verres, the rogue Roman governor of Sicily, living in and operating out of Hieron II's palace in Syracuse (Verr. II, 4, 54; II, 5 , $80)$, hints at the complex lived experience of Roman rule's continuities and

is Polarity and analogy: Lloyd I966; empires and linguistic mastery: Adams 2003, 637-4I on the Gallus inscription; Kuhrt 2007, I35-58 on the Bisitun (Behistun) inscription of Darius; imperium: Richardson I991; 2008, 43-4; 54; fasces: Schäfer I989, chs. 5, 7.

${ }^{16}$ The pillar base at Delphi: Plut. Aem. Paull. 28; Pollitt I986, I55-8; Ferrary 1988, 560-5; cf. Edmondson I 999 for the cultural gymnastics of Aemilius Paullus and Antiochus IV more generally; "upcycling": cf. Rous 2016. 
disruptions of preexisting institutions and their associated structures. The transition from kingdoms to Roman rule was played out also in cult. Subjects and allies sought to extend to the new Roman power established religious ways of thinking about monarchical power, and harnessed that power to the local community. The cult's complex struggle with monarchy is visible on many levels. The cult-figure of Roma is first attested in Smyrna in $195 \mathrm{BCE}$, and attestations rapidly increase after the fall of Macedon in $\mathrm{I} 68$. While the cult of Roma might remind us most immediately of the personified community of Athens or the demos, the cult, ideology, and trappings of the goddess Roma compare most closely with those of the Hellenistic kings. At the same time, cult was regularly addressed directly to individual Roman generals: "good" generals refused such honors, but "bad" ones did not, and there was clearly a hazy area in between. ${ }^{17}$

The idea of kingship continues to function as a Roman imperial resource well beyond its intervention in the eastern Mediterranean in the third to second centuries BCE. The Romans became king-makers, endorsing and even appointing the "friendly" kings who feature in Strabo's depiction of empire, although there was sometimes in practice greater ambiguity about who needed whom more than his account would suggest. These interactions with Rome further blurred the boundary between the Roman Republic and "foreign" kingship as kings increasingly adopted the ceremonial and behavior of Republican imperatores and were honored by gifts that the Romans imagined were appropriate to kings, a combination of recreated memories of their own regal past, experience of actual Hellenistic kings, and the more king-like costumes and attributes of high Roman officers and triumphant generals, including the curule chair, gold crown, and ivory scepter. Meanwhile, within the Roman state, consciousness of empire's traditional entanglement with monarchy encouraged attempts to regulate the conduct and careers of officeholders by norms and laws, even while competing Roman dynasts narrowed into a hereditary Roman monarchy. This consciousness would ultimately help to naturalize Strabo's equation between world rule and sole rule, as well as to formulate the peculiar institution of Roman monarchy. ${ }^{\mathrm{I} 8}$

17 Roman governors moving in to preexisting spaces: Haensch 1997; Meyer-Zwiffelhoffer 2002; Roman imperial cult: Mellor 1975; Beard, North and Price I998, vol. I, I 58-60.

18 "Friendly kings": Braund I984; Millar I996; cf. Cornwell 2015; distinctive Roman ideologies and practices of monarchy: Rawson I975; Wallace-Hadrill 1982. 
While much of the complex dance around monarchy takes place in the eastern Mediterranean, Iron Age Britain, at the northern edge of the Roman world, makes a fascinating case-study of how models of kingship gelled between local and international ideas. Julius Caesar's Gallic War, his account of his campaigns in Gaul and the first conquest of Britain, proceeds by polarity and analogy to write the political geography of Britain into recognizably international terminology, leaving space for the different and strange. Notably, his account identifies "kings," suggesting a complex process of interpretation in the translation of the term (e.g., $B G 5,20 ; 22)$. We tend to forget how crucially such intellectual processes underpin the practical workings of an empire that depended so substantially on local structures. On the British side, Iron Age coins suggest that local rulers drew eclectically on Hellenistic, Roman republican, and early imperial iconography, but could also find expression for the significance of older, local traditions. The coinage of Tincomarus in the south of England drew on the older, local significance of horses and ancestor cult in portraits that evoked the internationally recognizable equestrian pose and Octavian's self-representation as Divi F., "son of the deified Caesar" in its legend C. F., "son of Commius." ${ }^{9}$

The rich and dynamic interactions between Roman and local concepts of imperial figureheads do not end with the Republic. Portraits of emperors can be made to project a distinctive local vernacular, even in cases where communities were demonstrably well aware of the different kinds of images favored in Rome and Italy. Thus, the local people of Samos made at home both a portrait of Augustus as a very Roman exemplar of pietas with veiled head and a portrait of Augustus according to the conventions of a Hellenistic king, rather different from the distinctive "between citizen and king" model of the emperor in Rome and Italy. ${ }^{20}$

Roman rule's interface with kingship might be seen as a synecdoche for Roman imperial interfaces with local structures and expectations more generally. L. Aemilius Paullus' decidedly ambivalent Macedonian audience in 167 were informed that they would for the future pay to Rome half of the taxes formerly due to the Macedonian kingdom, and enjoy self-rule but rearranged in a new geography determined by Roman authority. It is hard to think of a better example of the subtlety of grafting new onto old, or of the sophisticated appeal to hard-wired ideas about the incompatibility of freedom and empire.

19 VA 375: S7 with Creighton 2000, I0I-5; I88-97; 2006, 35-45; Williams 2005, 73-7.

${ }^{20}$ Boschung I993, I 57 (plates 76, 2;3; I73, 2); I 56 (plates I76-7); Mayer 2010. 


\section{Making a Roman Imperial Dialect}

The traditional account of Roman imperial government is a bird's-eye view of the development of systems (provinces and taxation, the making and deployment of a standing army, the role and duties of the Roman governor) and of distinctive imperial ideologies. Such frameworks risk tracing institutions and ideologies as if they were substantially separable from their diverse fields and relationships of imperial engagement and are encouraged particularly by the legalizing approaches that we considered briefly in the first section of this chapter, and to some extent also by a semantic and literary focus. Interestingly, however, any narrow view of Roman imperial government that tries to nail its trajectory to what the Romans did or thought begins to collapse even and especially at the most empirical level. For example, the study of Roman imperial taxation necessitates thinking about the interface with earlier and competing systems, as well as the embeddedness of tax collection in local structures. This is an inspiring challenge as long as one does not retreat to a model of the Roman empire as "laissez-faire," one traditional means of maintaining the clean detachability of Roman systems from the mess of imperial contexts. The messiness of the contexts within which Roman imperial institutions developed will be a recurrent theme in the later chapters of this book. ${ }^{2 I}$

The Roman state was certainly capable of both interventionist behavior and not intervening in spheres where we might expect them to intervene, as we will see shortly. But recent, sophisticated work has emphasized the degree to which Roman imperial government was responsive rather than proactive, presupposing, reinforcing, and actively creating local structures, groups able to function as bargaining units, and even quite ordinary individuals (including women) attuned to the vagaries of the system. To study Roman government is therefore necessarily to think deeply about sites and modes of interaction and communication. ${ }^{22}$

An embedded study of Roman imperial government of this kind is one of the increasing visibility, and indeed domination, of motifs (linguistic, iconographic, architectural) and practices that suggest Roman sovereignty

${ }^{21}$ Superior accounts of Roman imperial institutions and ideologies include: Brunt I978; Bowman 1996; Eck 2000; Ando 2006; Richardson 2008; Roman imperial government as laissez-faire (sometimes qualified by economic or religious spheres, or in comparison with the later or late empire) e.g., Rostovtzeff I926, I 59; Salmon I944, 255.

22 Roman emperors as responsive: Millar I977; I984; cf. Crawford I990, I02 with n. 50 for its application to the Roman Republican empire; interaction and communication: especially Ando 2000. 
or channel systems and institutions of the Roman state, or localize imperial power in hotspots, even if these substantially co-exist with alternative loci of power. Examples include local appropriations of Roman magisterial titles and insignia, or of Latin or Latinizing vocabulary, formulas, legalese or material forms such as the "double document" occupying a register of power and efficacy. Another familiar manifestation of this phenomenon is acknowledging Roman coinage as the "top" coinage, and taking its forms, language, and iconography as the epitome of statehood. Elsewhere, architectural or iconographic motifs of the city of Rome were cited within discrete local contexts, or consensus was reached around distinctive, nonmetropolitan imperial modes of localizing power (e.g., the cult of Roma or temples of Capitoline Jupiter). We could also think of the readily recognizable and diffused iconography of the divinized imperial family, and its interference in the representation of both local divinities and prominent local individuals. We shall consider specific examples of this increasing visibility and its contexts in later chapters. ${ }^{23}$

The Roman state and its officers were acutely conscious of the power of spectacle, an important aspect of discussions of metropolitan political culture in recent years, particularly that of the politically dynamic middle and later Republic with its ceremonial, memory theaters and plain theatricality structuring, socializing, and reinforcing the social and political order. In the broader imperial sphere, the significance of spectacle is deeply dependent on context. Rome's earlier practices, notably the reconfiguration of the Italian landscape through centuriation and road-building, were informed by the ideologies and practices of competing powers as she emerged as a serious contender, first in Italy and then in the Mediterranean. Polybius' engagement with Roman use of spectacle is inevitably comparative, sometimes overtly so. Whether depicting atrocities visited on towns unfriendly to Rome (IO, I 5), or the ceremonial of a Roman magistrate (assuming that the treatment of L. Aemilius Paullus' settlement of Macedonia in Livy Book 45 is indeed rooted in a Polybian account), Polybius offers a sophisticated, discursive take on the implication of observers in interpreting and calibrating spectacle. ${ }^{24}$

If these are all examples of the grander, one-off spectacle of the Roman state and its officers, it is important not to minimize the impact and

${ }^{23}$ Interplay between imperial and metropolitan forms: Purcell 2000.

${ }^{24}$ Spectacle and metropolitan political culture: Hölscher I984; Linke and Stemmler 2000; Morstein-Marx 2004; Hölkeskamp 2005; 2006; 20I I; Beard 2007; early Roman spatial ideology and practices in context: Catalano I978; Purcell I990a; I990b. 
engagement of observers in the sorts of spectacle that will become more or less routine, ranging from the assize-circuit of a Roman governor to the much rarer journeys of emperors themselves. Above all, we should factor in the everyday performance of the privilege and power associated with the Roman state and imperial family on the part of minor Roman officials (soldiers, customs officers, imperial procurators), and indeed private Roman citizens and Italians (Roman by association in this context), sufficiently recognizable to be the focus of an orchestrated massacre in the "Asian Vespers" of the First Mithridatic War of 88 все (Val. Max. 9, 2, 3; Plut. Sull. 24, 4; App. Mith. 22-3), a massive anti-Roman spectacle.

Ancient empires of the Near East and the Mediterranean world traditionally staged participatory rituals in which rulers and subjects played distinctive parts. If the Apadana reliefs of Achaemenid Persepolis represent an idealized version of an imperial tributary system as the willing presentation of ethnically suitable gifts, the Athenian allies were required to bring their tribute to the festival of Dionysus and to participate in its procession. They also contributed a cow and panoply in the Great Panathenaea and were treated as if they were "honorary" Athenians. In the Seleucid Empire, exchanges of royal letters and local civic decrees sought to frame imperial power relations as the sort of reciprocal exchange of benefactions and honors that managed social relations within the polis. Roman imperial rituals, with origins at some point on a spectrum between institutions of the Roman state, Roman institutions formed "for export," and local practices, required their own, distinctive patterns of subject participation. These included the census, a Roman state institution that encountered parallel but not quite the same institutions in its imperial contexts, notably Egypt, extended first to Italy and from the Augustan age to the Roman Empire as a whole, the most obvious occasion for subjects to encounter Roman bureaucratic peculiarities. Orchestrated oath-swearing extended to provincial inhabitants (nominally, at least) older practices of soldiers swearing loyalty oaths to their commander, or subjects to their king. The practice of petitioning Roman dynasts and subsequently Roman emperors (or members of the imperial family) developed as the Romans progressively became the brokers of privilege and the arbitrators of the Mediterranean as well as much of the Near East and Europe. Besides encouraging the development of embassies as a new, translocal form of politics, it created ancient versions of "paper trails" that might cohere into applicable legal findings, instrumentalize local "memory theaters," or encourage the curation of cherished, valuable personal documentation, as well as habituating 
individuals and communities to a particular language of politesse, praise, and honors most likely to get things done. ${ }^{25}$

By writing of "spectacle," "performance," and "ritual," I would not want to minimize the sometimes catastrophic effects of physical and economic harm done to subjects within imperial contexts, but rather to emphasize the habituation of subjects to the particular expectations and opportunities of empire, from which some will indeed gain at the expense of others. But the language of "spectacle," "performance," and "ritual" also introduces a story within which the direct and deliberate intervention of the Roman state of its officers plays only a small part in comparison with some other premodern imperial systems. Examples from early (Qin and Han) China illustrate vividly paths not taken by Rome in the imposition of practices and customs: the universal application of a common script; the circulation of an authoritative state calendar; and imperial officials encouraged by rewards and punishments to impose the normative customs characterized as $\mathrm{li}^{26}$

These counter-examples from China point out major structural differences in the Roman case that are played out across sets of issues. These include the referral of authority over a community's religious practices to local officials without imperial oversight in both the charter of the Roman citizen colony of Urso of 44 BCE and the mid-third century CE decree of Decius on universal sacrifice. This is of course not "toleration," as the ejection or annihilation of practices associated with security threats to the Roman state and its holdings makes clear. In the correspondence between Trajan and Pliny the Younger, the emperor beautifully 'corrects' Pliny's knee-jerk reaction of thinking in terms of Roman law or material expertise within a provincial contexts, reminding him of the appropriateness of local custom and local resources (Letters IO, I7-I 8; 37; 39-40; 49-50; 6I-2; 68). The sporadic emergence of Roman officials specifically tasked with economic supervision within cities (curatores rei publicae) between the later years of the first century and early years of the second century CE, some of whom were requested by cities, and some of whom were appointed to cities that did not pay tribute, might suggest the importance above all of

${ }^{25}$ Apadana reliefs: Root 1985; Boedeker and Raaflaub 1998; Raaflaub 2009; requirements of Athenian allies: succinctly Osborne 2000, 98-9; Seleucid imperial exchanges: Ma 2002, chapter 4; on Roman imperial rituals, see especially Price I984; Ando 2000; cf. Revell 2009 for interesting attempts to use structuration theory to argue for the socialization of provincial inhabitants through specific spatial configurations, even if the theory promises more than the case-studies deliver.

${ }^{26}$ On intervention in Qin and Han China, see e.g., Bodde 1986, 56-8; Loewe 1986, 655-7; 686-8. 
the financial well-being that suggested the broader health of empire, delicately balanced between individual centers and the imperial whole. ${ }^{27}$

These illustrations of Roman structural difference might be considered alongside the notorious passage of Tacitus' Agricola, chapter 2I, in which Tacitus' eponymous protagonist, his father-in-law, steers the Britons toward a lifestyle that should neutralize security threats to Rome, an indirect form of disarmament. "Agricola" is present and offers encouragement and incentives in building (temples, fora, and houses) and lifestyle changes (hanging out in porticos, baths, and at feasts), until the Britons unknowingly and inadvertently enslave themselves in seeking to acquire highly desirable humanitas ("civilization"). The passage engages in much longer traditions of thinking about the luxury engendered by empire, but also tells a sophisticated (and not morally unproblematic), psychologizing, and surely over-coherent story about the extremely complicated and generally indirect relationship between Roman imperial presence and material change in provincial contexts. Although the passage has been read directly onto the fabric of provincial towns from Haverfield onwards, it is, importantly, a highly discursive passage that works on the level of esteem and self-worth with a mix of sociopolitical norms rather than operating as an architectural pattern book for a provincial town. We close the gap within imperial contexts between feelings, ideas, influence, preference, and norms at the interface of Roman state and local peoples, on the one hand, and precise material forms, on the other, at our peril. ${ }^{28}$

\section{Reproducing Roman Power}

Our discussion in the previous section of spectacle, performance, and ritual outlined some of the major imperial interactions that would habituate the inhabitants of empire to imperial systems as well as creating significance and even form. The analysis of the processes by which these imperial systems were created, communicated, understood, and applied has changed radically in recent decades. For much of the twentieth century,

27 Local religious authorities: Rives I999; Rüpke 2006a; 2006b; Ando 2007b; 2008, chapter 5.; for a critique of "toleration," see North I979; on curatores rei publicae, see Burton 1979; 2004; cf. the essays in Eck 1999 for the delicate calibration of local autonomy.

${ }^{28}$ For Tacitus Agricola 2 I, see e.g., Clarke 200I; Dench 2005, chapter I; for the role played by a Roman legate charged with "care of the temple" to be built by Smyrna to Tiberius, Livia, and the senate after the city was granted permission to build such a temple (Tac. Ann. 4, 55-6), see e.g., Burrell 2003, 29; Rubin 2008, II-I 2; cf. more generally Jones I997 for important problematization of reading ethnic self-identification from material culture. 
it was hard not to think of the chilling use of mass media by the Nazi and Fascist regimes of Europe in the I930s and I940s, including radio, film, and television as well as print, especially given these regimes' appropriation of classical imagery and reframing of Roman sites and artifacts. A centripetal model of magnetic attraction to a "Roman culture" that implies loyalty to Rome, somewhat along the lines envisaged by Haverfield (and for him very much a constant and inevitable aspect of empire), persisted within discussions of "Romanization" within the provinces that are concerned primarily with baths, pottery, and urbanization. Meanwhile, within the largely separable conversation about political culture of empire centered squarely on the city of Rome, the ghost of "propaganda" loomed large but encouraged big questions about the relative roles of message, medium, maker, and consumer. ${ }^{29}$

The nature of these questions can be illustrated by two different visions of the relationship between power and "culture" (in the sense here of the "high" culture of literature and fine art) in the Augustan principate across the twentieth century: Ronald Syme's treatment of ideology, poetry and historiography in two chapters (29: "The National Programme," and 30: "The Organization of Opinion") of his The Roman Revolution (first published, significantly, in 1939) and Paul Zanker's The Power of Images in the Age of Augustus (1988: the English version of the 1987 German book, Augustus und die Macht der Bilder). Syme's account of the Augustan principate is the story of the establishment of a "party," its members and adherents, including literary figures, rewarded by the goods and honors of patronage. Nevertheless, the literary talents of Virgil, Horace, and Livy elevate their works beyond propaganda, functioning as layers of interference in the promulgation of any singular imperial message, even if their loyalty is beyond question. In Zanker's vision, there is a more or less free flow between message, producer, and user in the normalization of a particular new fusion of imperial imagery and ideology (of new beginnings, moral rectitude, and the central importance of princeps and dynasty to this new world order) that enables its empire-wide reproduction and consequent saturation.

Zanker's Augustan world is to some extent the artistic expression of the growing tendency in the I970s and I980s to figure empire as a belief system in which subjects and inhabitants are significant actors and agents. This is the case even if the structures and processes and particularly the

29 For Europe of the I930s and I940s, see e.g., Visser I992; Ades et al. I995; Marchand I996, chs. 7-9; Nelis 2007. 
relative roles played by officers of the Roman state, producers and consumers in Zanker's world are more shadowy than they are in, say, Simon Price's more obviously social scientific account in Rituals and Power (1984), or Clifford Ando's comprehensive explication of empire as consensus in Imperial Ideology and Provincial Loyalty in the Roman Empire (2000). I have no desire to return either to the model of a "natural" pull toward the supposedly superior and more coherent culture of empire, or to that of the deliberate and total domination of minds implied by "propaganda." At the most basic level, neither model factors in the reliance on local structures that was fundamental to the workings of the Roman empire. But the model of empire as a belief system risks underplaying the significance of these local structures and agencies too, of equating reproduction too quickly with loyalty, and minimizing the friction, interference, mishearing, and redirection of energy that needs to be reintroduced lest the machine becomes too close to the dystopian, science-fiction vision of The Matrix (1999), in which what people experience as reality turns out to be simulated by machines fed by people's own body heat and electrical activity.

Andrew Wallace-Hadrill's incisive criticisms of Zanker's The Power of Images are applicable to the belief/consensus model of empire more generally. Wallace-Hadrill points to the existence of demonstrably variant "readers" of the architecture of Augustan Rome, most obviously Ovid, and to ongoing tensions in the adoption and juxtaposition of registers and systems of meaning (in this case, notably "Greek" and "Roman" systems) within and beyond the Augustan age. Wallace-Hadrill also suggests how a spelled-out version of Zanker's model of the process of reproduction of imperial imagery might complicate things, through an example from his own work on the numismatic iconography of victory and virtue. The coin user has a stake in the prestige and winning quality of the imperial imagery that is distinct from that of the maker (let alone that of the emperor, a notoriously difficult role to pin down in the early Empire): the prestige and winning quality associated with the imagery is transferred to the coin itself, with implications for the success and faithfulness of the transaction. In the context of the empire of belief/consensus more generally, to focus more squarely on users and contexts of use is to raise questions about the singularity of the belief system, its relationship with other systems, and who or what benefits in the process. ${ }^{30}$

30 Wallace-Hadrill i989b; cf. I 986. 
To develop this argument, I begin with the phenomenon of reproducing in non-Roman contexts the rituals, performance, or iconography associated with the power of the Roman state when this demonstrably has nothing to do with loyalty to Rome. Earlier in this chapter, we considered the story of the Seleucid king Antiochus IV dressing up as if he were canvassing for a Roman magistracy and performing the duties of a Roman magistrate as an illustration of imagining a powerful kind of sovereignty that was the "opposite" of kingship, in the form of the Roman Republic. Availability of this alternative recurs in ancient traditions on Salvius the leader of the second Sicilian slave war. Traditions on both Eunus, leader of the first Sicilian slave war (135-32 вCE), and Salvius of the second (IO4-IOO BCE), are densely interwoven with motifs of contemporary kingship in the eastern Mediterranean, notably references to the Seleucid kings: Eunus' alter ego, "Antiochus," in whose name he minted coins, ("basi(leos) Antio(chou)"), is a dead giveaway. But traditions on Salvius (whose alter ego, "Tryphon," was not at all coincidentally the name of a Cilician pretender to the Seleucid throne in Syria) are even more interesting: he is made to assume a hybrid costume that pairs Roman toga with chiton, the generically "Greek" costume of the increasingly polarizing world of the second-century Mediterranean, and to have lictors bearing axes go in front of him. Diodorus Siculus, the Sicilian Greek narrative historian of the late first century вСE, interestingly sums up his performance as "and in general he affected all the trappings that go to make up and embellish the dignity of a king" $(36,7,4)$, perhaps implicitly acknowledging the blur between Roman imperator and king in signaling sovereignty at this time. ${ }^{3 \mathrm{I}}$

As we move into the first century $\mathrm{BCE}$, the iconography and might of the Roman state are increasingly visible in the claims of rebels and pretenders. Notoriously, in the Social War of 9I-89 в С, the rebellious Italian allies minted coins that closely mirrored the coinage of the Roman state in weight, denomination, and iconography, and even described the Samnite general C. Papius Mutilus as embratur (the Oscan version of imperator) even as the bilingual Oscan-Latin legends and the coins' message - at their starkest, the Italian bull goring or raping the Roman wolf - insisted on separatism and domination. The literary tradition on the rebel allies' political organization and aspirations at their capital, Corfinium (significantly renamed Italica), explicitly mirrors the Roman

3I Shaw 200I, I07-29. 
state, with a senate of 500, two annual consuls, and I 2 praetors (Diod. Sic. $37,2,4-7) .^{32}$

The trajectory of the third-century CE self-representations of Zenobia and her son Vhaballath makes for a suggestive case-study from the "high" empire. This noble family of Syrian Palmyra elevated their realm to a "kingdom" and until the spring of 272 , in the time-honored fashion of locals co-opted into the service of the Roman empire, they guaranteed the military security of the Roman empire against the Parthian empire to the east, initially under Zenobia's husband Odaenath and then, after his death, under Zenobia herself and their son Vhaballath, whose Aramaic name means "gift of Allath." Vhaballath was a Roman citizen, whose full name, Lucius Iulius Aurelius Septimius Vhaballathus, records close connections with the dynasty of Roman emperors and hyphenates his Palmyrene origins, retaining his Aramaic name as a Latinized cognomen. Their selfrepresentation was at first culturally eclectic, but careful to acknowledge the supremacy of the Roman empire. Their coinages utilize the three languages of Palmyra (Latin, Greek, and Aramaic), and draw selectively on three different cultural traditions with some points of intersection: young gods of Palmyra, "friendly kings" of the Roman empire, and the "king of kings," the formula used by rulers of the Parthians and Sasanians who set themselves in the tradition of Achaemenid Persia. On coins minted at Antioch and Alexandria, Vhaballath's portrait on the reverse is twinned with the Roman emperor Aurelian on the obverse. Aurelian, as Imperator Caesar Aurelianus Augustus, appears with his radiate crown, while Vhaballath appears with his diadem and laurel wreath, looking two ways, to Greek and Roman pasts. On other coins, he is portrayed with long hair, perhaps an allusion to the local "young gods" of Palmyra.

From the spring of $272 \mathrm{CE}$, Vhaballath and Zenobia broke away from the Roman center and started ruling in their own right. The more independent and dangerous they became, the more they portrayed themselves exclusively as Roman emperor and empress respectively. On coins, Vhaballath was completely slotted in to the iconography of third-century emperors, with his crown, short hair and titles ("Imperator Caesar Vhabalathus Augustus") (Figure 2). By the third century CE, when it came to asserting imperial power in the traditional territory of the Roman empire, it was hard to envisage being anything other than a Roman emperor. ${ }^{33}$

Appropriating dominant forms of sovereignty is not the only way of framing a rebellion. The destruction of statues, representations, or shrines

\footnotetext{
32 Wallace-Hadrill 2008, 88-9. $\quad 33$ cf. Long I 996; Schwentzel 2010; Butcher 2003, 328.
} 


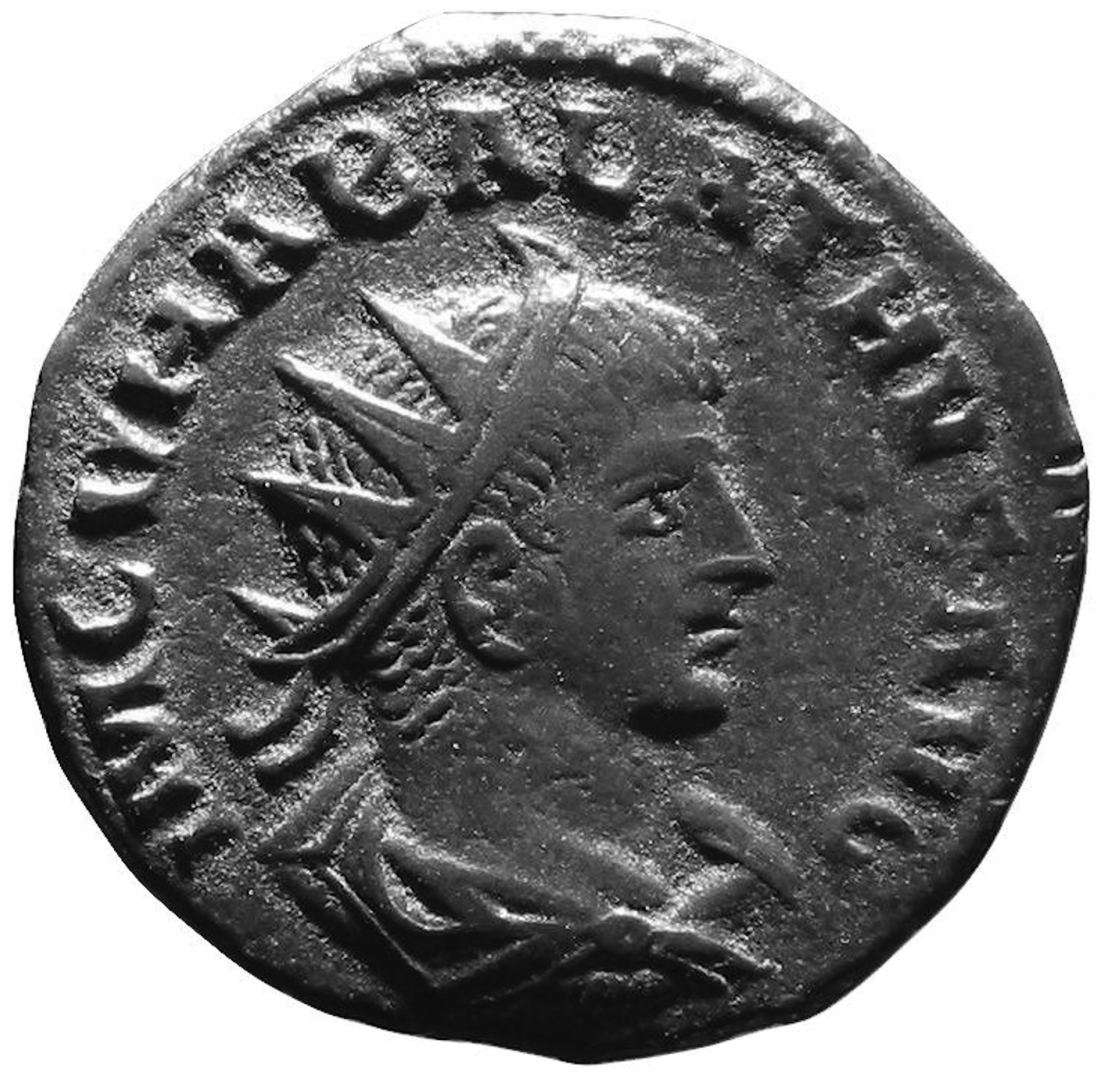

Figure 2 Obverse of silver Antonianus of Vhaballath of Palmyra with radiate crown as Im(perator) C(aesar) Vhabalathus Aug(ustus), uncertain mint,

272 CE, ANS i944. I00.30790.

Courtesy of the American Numismatic Society.

that distill the ruling power in the most concentrated way is familiar from the Roman world and revolutions the world over, while refusing to be taxed is similarly incendiary. Language and particular facets of religion and culture can become highly charged and used in self-identification with groups and states distinct from and at odds with Roman rule. Certain cases of this phenomenon can be identified relatively easily, notably the exclusive use during the Great Revolt of 66-70 and the Bar Kokhba Revolt of Hebrew and paleo-Hebrew slogans on the coinage of the insurgents. In the case of the Social War bull and wolf coins, the aggressive nature of this image encourages us to see the gap between these and coins of the Roman 
state, as well as aspirations to statehood implied by the appropriation of formal aspects of Roman coinage. ${ }^{34}$

In the last part of this chapter, I will consider the quieter reception of tropes of Roman power that do not always look to the Roman center or necessarily entail loyalty to central Roman authority. Roman rule profoundly changed the structures of local societies, and the fact of Roman sovereignty was marked in every sphere of life. But we find numerous examples of individuals and groups who seek to harness the efficacy of Roman power to all sorts of personal and local ends, that, however benign, have nothing to do with loyalty to the Roman center.

My first set of examples concerns the representation and selfrepresentation of local magistrates. From the second century вСE, long before there was anything particularly desirable about adopting Roman culture outside the city of Rome, and long before the city of Rome functioned as a model for civic communities, we see the proliferation of Latin loan-words for Roman magistrates in the Latin and Oscan inscriptions of Italian towns that were still at that time subject to Rome. Loanwords, such as pretores and kvaisstures, appear alongside more traditional meddices and other local designations. These Latin loan-words helped to express the new diversification of office in Italian communities, but they also represented the appropriation of elements of the imperial power to which the Italians were subject into strictly local situations. There is no doubt here that the Italians believed that Roman power was efficacious, and even the epitome of a dominant power, but there are no particular implications of loyalty to that Roman power: many Italian communities notoriously fought against Rome in the Social War of $9 \mathrm{I}-89$ в Се. ${ }^{35}$

By the end of the Republic, the status of cities in relation to Rome in Italy and the west was formally defined in legal charters, a process that paralleled the incorporation of individuals into Roman citizenship. The responsibilities of local magistrates of Roman colonies and other privileged communities were set out in these legal charters, with explicit references to city of Rome practices. In theory, communities and individual magistrates knew their place, which was inevitably subordinate to the city of Rome and its magistrates. Town charters contained clauses that specified the number and type of attendants wielding bacilla (axe-less fasces) a local magistrate could have, significantly fewer than a high magistrate of Rome.

\footnotetext{
34 Jewish coins: Schwartz I995, 27; the visibility of the gap in mimesis: Bhabha I994a; Fuchs 200I; problems of reading resistance from material culture: Jiménez 2008.

35 Campanile and Letta I979.
} 
The "rule book" mentality plays a significant role in the making of a juridically Roman or Latin town in the early Empire. Holders of the duumvirate, the top magistrates in Latin and Roman towns, were allocated one pair of bacilla-wielding lictors, compared with the six pairs attending a Roman consul. Jurisdiction was circumscribed, and military command under local officials' own auspices and independent foreign policy were obviously out of the question. ${ }^{36}$ Augustan legislation and actions of the princeps reinforced notions of order that emphasized the distinct place of groups and individuals within a hierarchy: theater-seating legislation models this beautifully, as we will see in Chapter 3 . The very emergence of a princeps focused attention keenly on gradations of power, such as questions about the appropriate recipients of a triumph and suitable spaces for the self-display of senators and other individuals outside the imperial family. Ironically, this encouraged a more clearly articulated "Republicanism" than ever before.

So what are we to make of the (probably) early Augustan monument honoring C. Cartilius Poplicola (Figure 3), dedicated in a lengthy inscription "at public expense ... by decree of the decurions and consensus of the colonists," to the eight-times holder of the office of duumvirate in the Roman colony of Ostia and three-times censor, as well as to his children, descendants and wife? The imposing marble monument is decorated with a triumphal-type frieze depicting a sea battle, as well as infantry and possibly cavalry, no fewer than 16 bundles of bacilla flanking what may originally have been a representation of a curule chair, and was almost certainly topped off with a rostrum (ship's beak), the paraphernalia of naval victory. ${ }^{37}$

On an obvious level, the monument looked to the Roman center, taking its inspiration from the highest Roman officials of the Roman Republic, and perhaps even from the archaizing exceptionalism of Augustus himself. Scholars have suggested an exact parallel for the rare adjective used to describe Poplicola, preimarius, "first and foremost": the famous elogium of the mid-third-century вСе consul and censor A. Atilius Calatinus. This elogium had enjoyed something of a revival in the late Republic, perhaps encouraged by wishful thinking about the emergence of a positive kind of first man. The Ostians' choice of Poplicola as duumvir "both in absentia and while present" is also signaled, and this association of

${ }^{36}$ Lex Coloniae Genetivae 62 (Crawford I996, 25 with note at p. 433); cf. Schäfer I989, 2 I7-2 I.

37 Inscription: Bloch 1958 with Panciera 1966; monument and its decoration and date: Squarciapino I958; Gismondi I958; Schäfer I989, C7, 385-6 with plate 93, I; Pensabene 2004. 


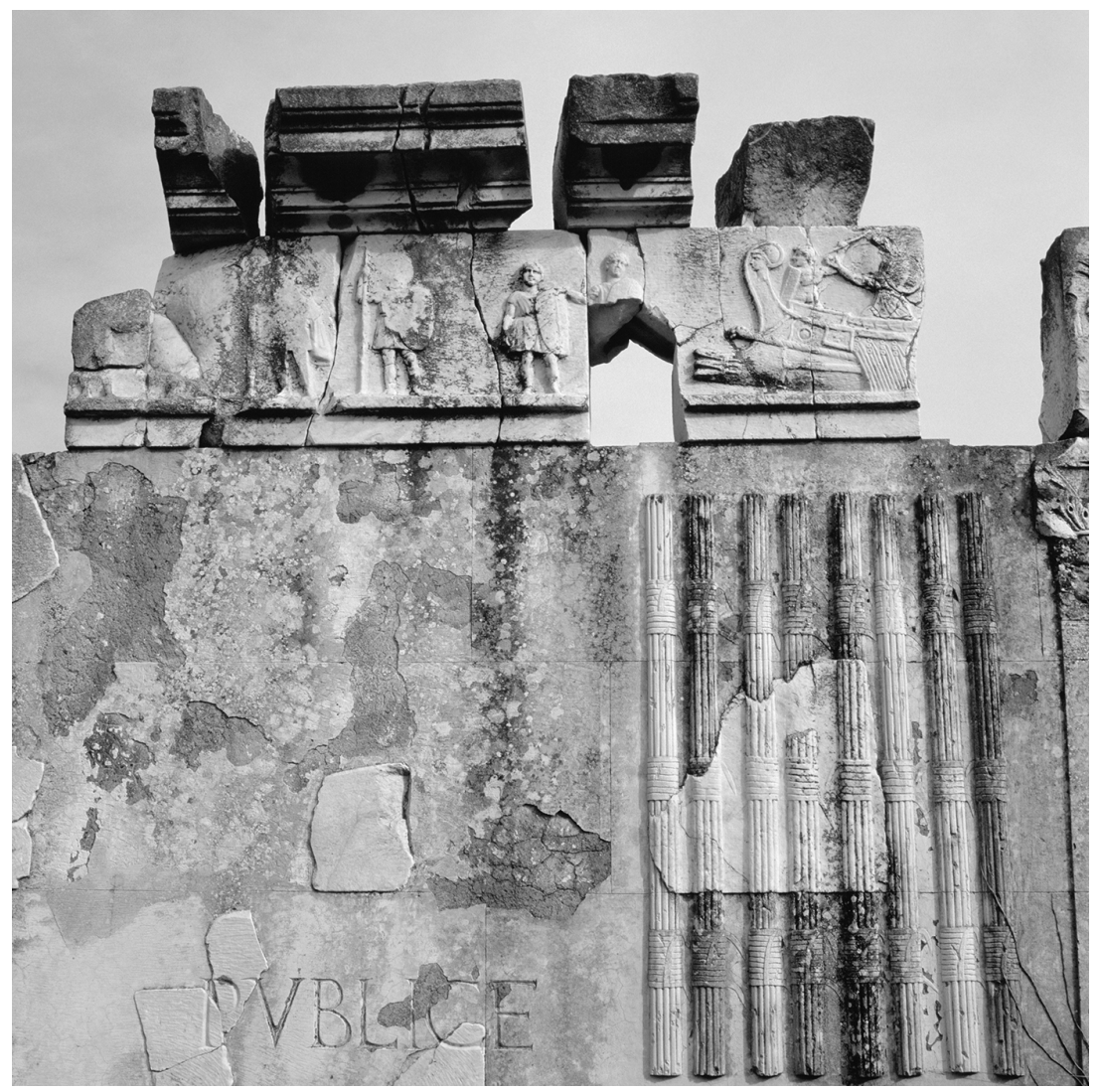

Figure 3 Heavily restored monument to C. Cartilius Poplicola of Ostia, eight-times duumvir and three-times censor, showing one half of eight pairs of bacilla (axe-less fasces), frieze with sea battle and infantry soldiers, and beginning of long inscribed dedication "at public expense." Probably early Augustan, outside the Porta Marina, Ostia. Photo by Art Media/Print Collector/Getty Images.

in absentia elections with exceptionalism has a particularly Augustan ring to it. This emphasis on in absentia election will find a famous historicizing parallel in the elogium of Marius, traditionally attributed to the Forum Augustum, finally dedicated in 2 в $\mathrm{CE}\left(C I L 6,4 \mathrm{IO}_{24}\right.$; Inscr. It. I 3, 3, I7): "three times he was made consul in absentia." The very cognomen Poplicola, "the People's Friend," which C. Cartilius apparently acquired at some point during his second duumvirate, almost certainly recalls that of the suffect consul of the foundational year of the Roman Republic, the 
colleague of Brutus, and iconic expeller of kings, named Poplicola by the grateful (and arguably rather fickle) people, finally reassured that he was not aiming at tyranny. Livy's account of the Poplicola story, with its complex negotiation of kingship, suggests how this episode resonated in the early years of the principate $(2,7,3-8,4) .^{38}$

Poplicola's memorial has generally been interpreted as an endearing example of the kind of "over-expression" associated most readily with freedmen Augustales or vicomagistri, perfectly aware of their humble position in the Roman imperial eco-system but a little starstruck by the Roman imperial center with its associated ceremonial. In the case of a Roman colony like Ostia around the turn of the eras, we would probably talk rather about an equally endearing and anodyne "local pride," based on Ostia's ancient and special relationship with Rome, newly manifest in a developed sense of what it was to be a Roman city. I would of course not want to deny the Ostians' pride in their celebration of Poplicola, or to see anything non-benign in their "over-expression" of his achievements and virtues: Ostia was, after all, an "extreme" Roman colony, believed to have been founded almost at the beginnings of Rome itself. But I do want to think of the monument within a much broader context of empire-wide engagement in or reproduction or appropriation of rituals, insignia, or hotspots that suggest Roman sovereignty or reproduce Roman centrality at home, and at one end of a long spectrum of that runs all the way via gaming the system or siphoning a bit off for yourself or your community to outright usurpation of the executive power of the Roman state. ${ }^{39}$

Viewed within this context, the Ostian monument is a striking statement of statehood expressed in the symbolism of a world power. We might single out the astonishing display of multiple axe-less fasces, a celebration of the power to enforce that stops short of execution, and a reminder of the centrality of coercion in the reception of imperial power and violence as an expression of self-determination. Also striking is the princeps-like exceptionalism of their leader, played out as a distillation of grand statesmanship, culminating in an Actium-like sea battle (and perhaps the grandest imaginable battle, by all conceivable means). Last but not least, we should note the Ostians' showcasing of their sovereign political institutions ("colonists" and "decurions," as well as officers such as Poplicola) in action

${ }^{8}$ Inscription's language of exceptionalism: Bloch 1958.

39 Freedman paramagistrates and “over-expression": Whitehead I 993 (cf. Petersen 2006 for critique); cf. Prag 2006; Laird 2015. 
(electing and honoring, their political community perhaps mirrored in the "brothers-in-arms" iconography of land soldiers in the frieze). ${ }^{40}$

The Poplicola monument is an excellent illustration of the impact and internalization of Roman imperial symbolism. This arguably extends even to the internalization, at least on one level, of rules that reinforced hierarchical relationships. It is hard to believe that the 16 bacilla represented on the monument are "only" a multiplication of the two axe-less fasces to which Poplicola, as duumvir, was entitled, by the eight times that he held this office (let alone "only" artistic license). But the mathematical precision, as well as the absence of axes, remains suggestive of an applied legalism and awareness of how far to push the boundaries of possibility and respectability. At the same time, there is a magnificent boldness in this boundary-pushing, which reminds us of other, less benign and more selfinterested acts of appropriating the paraphernalia of the Roman imperial state and diverting its power and efficacy to ends that have nothing to do with enacting loyalty to the center.

The so-called "Babatha archive" takes us well beyond receptions of the authority and power of the Roman empire on the part of Roman citizens or those who were close to Roman citizenship in status. ${ }^{4 \mathrm{I}}$ Babatha was not a Roman citizen, but a wealthy Jewish woman, who lived in the "friendly" Nabataean kingdom, which became during her life time part of the Roman province of Arabia (established in $106 \mathrm{CE}$ ). Her "archive" is a collection of legal documents dating from between 96 and $\mathrm{I} 32 \mathrm{CE}$, detailing her affairs and those of some of her family members. They were found in a leather bag in a cave near the Dead Sea. It has been conjectured that Babatha fled to the cave during the Bar Kokhba Jewish revolt (I32-I35 CE) and never returned home. The documents are written in Nabataean Aramaic (the major language of the Nabataean kingdom), Aramaic (a legacy of Persian rule and influence), Hebrew (the language of Jewish scriptures and hence a cultural, religious, and ethnic marker of Jewish diaspora communities in the Roman empire), and Greek (the major language of official business in the eastern Roman empire, as we have seen). Some individual documents are written in a combination of several of these languages. Babatha's complicated personal life, including her two marriages and disputes with

\footnotetext{
40 Actian imagery of late first century BCE: Avilia and Jacobelli I989; Kellum 20 Io.

4I For what follows, see fundamentally Lewis, Yadin and Greenfield I989; Bowersock I99I; Goodman I991; Isaac I992; Cotton I993; Millar I993, s.n. "Babatha"; Yadin, Greenfield, Yardeni and Levine 2002; Katzoff and Schaps 2005; the Babatha "archive" illustrates beautifully the "ground-up" workings of Roman legal culture discussed by Humfress 20I I; 2013.
} 
a number of people over the guardianship of her "orphan son," Jesus, her son by her first husband, and over property, can be reconstructed from contracts, summonses, and other documents. While the persistence of such documents as land leases, sales, and marriage contracts in "Semitic" languages suggests the plurality of authorities after the establishment of the Roman province of Arabia in $106 \mathrm{CE}$, the degree to which Babatha sought the authority of Roman rule to resolve her various problems is striking.

The presence of Roman authority is most overt and direct in a copy of a census document dating to I27 (P. Yadin 16) and in a number of summonses and counter-summonses before the Roman governor, issued by and against Babatha (P. Yadin I 4; cf. I 5; 23; 25; 26). The census return is a fact of Roman rule, not a matter of choice, but the summonses suggest a willingness to turn to Roman authority, and specifically the highest Roman authority available at the local level, the governor, to resolve disputes. This was a facility that was learned very quickly during the first generation of direct Roman rule. A number of the summonses relate to the guardianship of Jesus, and the "archive" includes three copies of a Greek version of the Roman praetor's pronouncement on guardianship that we know about from Gaius' Institutes (P. Yadin 28-30; cf. Inst. 4, 47). Although Jesus' guardian had been appointed by the local city council of Petra, Babatha pursued this important personal issue extensively through Roman rather than local legal avenues.

Elsewhere, Roman authority is targeted much more loosely, rather than appealing directly to the Roman governor as judge or invoking Roman law. One excellent example is the marriage agreement of I 28 CE between Babatha's stepdaughter Shelamzion and "Judah, surnamed Cimber" from En-gedi on the Dead Sea in Judaea (P. Yadin I 8). While Babatha's own second marriage document was written just a few years earlier in Aramaic, the contract between Shelamzion's father and her husband is written in Greek, and refers explicitly to "Greek" custom, although the parties and witnesses sign off on it in Aramaic. The extent to which the arrangements reflect Jewish practice has been much debated. The document begins by identifying the year both by consular dating and by reference to the new province of Arabia, striking echoes of Roman official practice. The scribe indicates his "job-title" by a Latin word transliterated into Greek, probably libellarius. These various features reflect the reception of new models of what an "official" document looked like, whatever the realistic nature of its target audience. It should be Greek, an "official" language of the eastern empire used by both the city councils and institutions of Roman 
administration in a way that local, "Semitic" languages were not. It should have distinctively "Roman" features, especially in dating formulas that seem almost to define official discourse, and the odd loan word from Latin will only increase the authority of a document.

As if these features were not enough, the document was clearly intended to look "official" at very first glance, and without anyone needing to read it: like other documents in the "archive," including even some written in Aramaic, the papyrus was folded in an obvious reference to the wooden tablets that were associated specifically with official Roman contexts, such as census returns or military diplomata. This phenomenon has been illuminated in Elizabeth Meyer's eloquent study of tabulae, often called "double documents," because there are distinct inner and outer sides, with the outer side typically summarizing the inner one. These local approximations are far from homogeneous, as the languages and materials of the documents in Babatha's "archive" illustrate. Most importantly, this phenomenon gives us a beautifully complicated sense of "consensus." Local peoples might certainly use the double document form (and the legalese that went with it) to target the Roman authorities specifically, for example when sending a petition to the governor. But these forms are also employed in contexts which Roman authorities can never have been intended to see, such as marriage contracts written in an unfamiliar language. ${ }^{42}$ This approximation of a specifically "Roman" official form appears to be expected to work far beyond the reach of Roman authority: to some degree it has taken on a life of its own.

By the late first and early second centuries $\mathrm{CE}$, the degree to which specifically Roman trappings of power and authority are "targeted" by local groups and individuals is striking. It was not the case, however, that Rome was the only source of power and authority so targeted. On both the human, political plane and the divine plane, there were attractive alternatives, as the Palmyrenes' choice of the Parthian/Sassanian "king of kings" and the phenomenon of hyphenating gods in the western and northern provinces, such as Minerva Sulis and Apollo Granius, illustrate. These plural sources of power are not evidence of passive "survival" but of the continuing, dynamic processes of translation, equivalence, and distinction that were features of the beginnings of Roman overseas expansion.

42 Meyer 2004, especially I78-206; cf. 54-5; I03-7 for the tabula form and legal language of Roman curse tablets, and the legalese of British curse-tablets, following Tomlin I988, 70-I. 


\section{Roman Middle Grounds}

Richard White's The Middle Ground (I99I), a case-study of the early history of encounters between Europeans and Native Americans in the Great Lakes region, offers a suggestive model for thinking about the dynamic interface between Roman rule and competing systems and local structures. White characterizes a situation in which "badly frayed or even cut" cables run out from the centers of French imperial power, as they lose the power to control and coerce and have to compete with other loci of power, the Iroquois, Algonquians, and smaller entities, such as Huron, the Illinois, the Miami, and the Ottawa as well as more distantly, the British. His "middle ground" erodes only gradually, initially in fits and starts, as European approaches switch from mediation to coercive alliance, from upholding the authority of chiefs to dictating terms to them, and, from the I750s, with the arrival of competing imperial armies of occupation, the French and the British.

In the case of the Roman empire, the power to control and coerce was of course the aspiration of Roman imperium, and threat and terror very real: we shall explore the role of force and violence in the rhetoric and practice of imperial relationships in Chapter 4. But the thinly stretched nature of that Roman power, or at least its coexistence with competing systems of power and authority is clearly visible in the making of empire, at its edges and at times of crisis. Parallels with White's "badly frayed or even cut" cables are most obvious here. What I have argued in the last section of this chapter is that there are suggestive parallels to some extent also in everyday, businessas-usual Roman imperial relationships, encouraged by the substantial reliance of the Roman empire on local authorities and structures for even basic functions of state. This phenomenon becomes hard to see if we join the dots between periodic articulations of rules that more clearly nest local authority within and subordinate to central imperial power, and because it can be hard to look beyond the comparative domination of Roman imperial motifs, and more closely at structural contexts, interests, and ends. ${ }^{43}$

43 I fully take on board Andrade's criticisms (2013, I I-I 4) of the use of White's "middle ground" theory to characterize the articulation of cultural identity as if there were bordered entities of "Greek" versus "Syrian" etc. I am concerned rather to read "middle ground" theory in terms of the stretched and gappy quality of imperial power. 